\section{Exploring the Factors Associated with the School Dropout}

\author{
Adnan Boyacı*
}

$\begin{array}{ll}\text { Received: } & 10 \text { August } 2019 \\ \text { Revised: } \quad 22 \text { October } 2019 \\ \text { Accepted: } \quad 18 \text { November } 2019 \\ \text { ISSN: 1307-9298 } \\ \text { Copyright C IEJEE } \\ \text { www.iejee.com }\end{array}$

DOI: 10.26822/iejee.2019257661

\begin{abstract}
The aim of this study is to critically examine the sociodemographic and individual factors leading to school dropout. The study uses the Family Structure Survey (FSS) data collected in 2016 from 35.475 household members 15+ years old, by Turkish Statistical Institute (TurkStat). Appropriate variables, gender, marital status, age, work status, living away from mother, living away from father, and the residential area were chosen as the predictor variables of the odds of dropout behavior in any level of education for specific age groups. According to the binary logistic regression, being married, working in a job, living in a village or county and living away from father or in a separated family are the major sociodemographic problems leading dropout. Besides, economic issues and low achievement is the major reasons to dropout according to the participants' views by descriptive statistical analyses. In this regard, taking comprehensive actions to minimize the effect of these factors with a broad cooperation and collaboration of the national, local and institutional authorities is suggested and the need for more studies specifically designed for rural and urban areas is emphasized.
\end{abstract}

Keywords: School Dropout, Socioeconomic Background, School Dropout Factors

\section{Introduction}

School dropout is an unwanted result in one's period of education, not only because of losing individual gains sustained by education but also because of its negative collective results in the whole society (Kronick, 1994). Lots of studies show that dropouts are more likely to become unemployed, to work for low wages, to have health problems and to have criminal records than the non-dropouts (Belfield \& Levin, 2007). Considering the transformative role of education, school dropout naturally hinders to achieve learning outcomes, and accordingly, causes the waste of resources allocated for education in every level (Boyacı, Karacabey, \& Öz, 2018; MoNE [Turkish Ministry of National Education], 2013; Uysal, 2008).

The international debate on the school dropout is mainly focused on this unwanted behavior in the elementary and secondary education levels, figuring out the duration of compulsory education generally covers the elementary or secondary education all around the world (data.worldbank. org). Besides, the lack of access to quality elementary and secondary education in low-income countries, lead global actors like UNESCO, UNICEF and World Bank (WB), to focus on dealing with school dropout and the factors causing attainment problems in these educational levels. As an exogenic factor, the nature of higher education as a private good, is also playing a suppressive role on shifting the center of this debate from higher education to secondary and elementary education. In other words, higher education is up to individuals' will, whether they attend a university or not.

In Turkey, school dropout phenomenon is also studied same as in the international scholarship. The focus point is the elementary and secondary school dropout mainly. Most of the academic studies (Gökşen, Cemalcılar, \& Gülselel, 2006; Bülbül, 2012; Karacabey \& Boyacı, 2018; MoNE, 2013; Özdemir et al., 2010; Özer, Gençtanirim, \& Ergene, 2011), and the national projects or programs (ikg.gov.tr; tegm.meb. gov.tr) related to school dropout and enrolment focuses on the elementary and secondary education levels. Consider- ing the extension of compulsory education in Turkey from eight years to 12 years in 2012, and the principal of providing equal opportunities in the basic law of national education (Law Nr. 1739), the focus on the school dropout in elementary and secondary education is quite normal. Similar to the international context, dropout in higher education is often disregarded in Turkish literature. The main reason is again the higher education is often regarded as a private good and it is a non-compulsory level of education. Turkey is one of the countries in the world in which more than 100 state owned universities are free of charge.

In this study, it is aimed to identify the leading factors to dropout. But unlike the majority of studies in the literature, there isn't a specific focus on educational levels, but age categories. In this context, this study takes a broad picture of school dropout in any level by age groups. There are two main reasons by doing that.

Firstly, difficulty of defining who is a dropout in the levels of education. In secondary education level, the non-continuous structure of the new system eased the passage of students graduated from formal lower secondary schools to Open Upper Secondary Schools. And the students in the Open Upper Secondary Schools are again treated as the ones who are in formal secondary schools in the yearly national education statistics, but they are regarded as dropouts in the Electronic School System of the Ministry of National Education (MoNE, 2013). So, the proportion of the students in Open Upper Secondary Schools can give a clue about the total proportion of high school dropouts. The proportion of the students enrolled in Open Upper Secondary Education is 24.53\% in 2018 (MoNE, 2018). Besides, this is not the only information on the rate of school dropouts in Turkey provided by MoNE. Early leaving rate in education is $34.81 \%$ (\% of a person aged 18 to 24 who has completed at lower secondary education), while the rate of out of school student in secondary education is $5.47 \%$ (PoSD, 2017). Hence, although there are various rates of school dropouts based on various definitions, there is not a consensus of who is the actual dropout. 
The second reason is the often ignorance of number of dropouts in the tertiary education and the scarcity of studies on the college dropout or persistence in the Turkish literature. Although the dropout term is often related to elementary and secondary education, the proportion of students leaving universities is actually showing incongruity to the quantitative developments in Turkish higher education in the last decade. In other words, despite the recent increase in the number of universities and enrollment rates in higher education, there is an ongoing rate of students who retake the university entrance exam while already enrolled in a university or after graduation. This is due to the fact that many students want to get access to another study area than the one they already enrolled. In 2017, there were 193,715 people graduated from a university and 523,381 students enrolled in a university retook the university entrance exam when the total number of applications was 2,265,844 (MoNE, 2018). This means $31.65 \%$ of the applications have already had a university experience, but because of various reasons they wanted to retake the exam to change their departments or universities they already enrolled as students, as mentioned earlier.

In conclusion, this study is not limited with a specific educational level when exploring the factors leading school dropout. Yet there are some limitations. The dataset used in this study is taken from the Family Structure Survey (FSS-2016) of Turkish Statistical Institute (TurkStat, 2016). So, the factors leading school dropout are restricted with the appropriate variables in the survey, since it covers a broad variety of topics regarding family structure. There are three main parts in the FSS as Main Characteristics of Household Members' Questionnaire, Household Questionnaire and Individual Questionnaire. The data was collected through the face-to-face interviews with the individuals aged 15 and over, living in the sample households. In this study, only the Individual Questionnaire was used.

Therefore, this study could make a great contribution on the identification of some certain factors leading school dropout by using a national, large-scale survey, which has a great capacity of affecting political actions towards the dropout problem

\section{Different Conceptual Frameworks for Explaining Dropout Phenomenon}

Basically, school dropout is the change of a certain behavior not going to school anymore. A broad variety of factors could be able to lead that behavior, considering the place of the student in a certain environment. In a broad sense, this environment refers to student's social class, and the cultural capital, human capital, division of labor and the anomies in this class could give lots of clues regarding the possible school dropout behavior (Karacabey \& Boyaci, 2018). From a narrow perspective, this environment could be the family, school and the community where the student has got close social networks (Israel \& Baeliu, 2004). In this regard, school dropout is the result of a developmental process consisting of lots of experience through one's educational period in those environments (Jimerson et al., 2002).

There are various models or conceptual frameworks trying to explain school dropout. But they are basically differentiating for K-12 education and post-secondary education. Frankly, most of the time these models focus on school dropout in K-12 education, and student retention or attrition in post-secondary education. So, pushing/pulling factors (Jordan, Lara, \& McPartland, 1994; Stearns \& Glennie, 2006) student engagement model (Newmann, Wehlage, \& Lamborn, 1992), developmental-transactional model (Jimerson et al., 2000), frustration-self-esteem and participation-identification models (Finn 1989), five theories (academic mediation theory, general deviance theory, deviant affiliation theory, family socialization theory and structural strains theory) of Battin-Pearson and others
(2000) and the conceptual model of high school performance (Rumberger \& Lim, 2008) consist of the dropout models or approaches in K-12 education.; whereas, student involvement theory (Astin, 1985), student integration model (Tinto, 1987), the general model for assessing change (Pascerella, 1985) and the model on dropping out of residential and commuter colleges (Braxton \& Hirschy, 2005, p. 69-74) are the major models or approaches in the student engagement, retention or attrition in post-secondary education.

\section{Models or Conceptual Frameworks of Dropout in K-12 Education}

One of the approaches for school dropout can be expressed as the factors that push out of school and pull out of school (Jordan, Lara, \& McPartland, 1994; Stearns \& Glennie, 2006). In this regard, it is possible to talk about a number of internal and external factors that play a role in the dropout process. Pulling factors arise from the external environment of the school and the student's personal life, like financial status, work status, changes in the family structure, marriage or some other out of school factors, and could be effective on staying in the school or dropping out. However, pushing factors are composed of in-school factors. The attitude of teachers towards students, disciplinary policies, school rules, examinations, tests, and low grades could be able to push the student out of school. Hence, problems arising from the school structure is also essential for staying in school or dropping out.

Student engagement model (Newmann, Wehlage, \& Lamborn, 1992) propose another approach for explaining school dropout behavior: Student engagement is able to hinder alienation and strengthen the attainment. Students engage in educational processes behaviorally, effectively and cognitively (Fredricks, Blumenfeld, \& Paris, 2004). In this context, the involvement of students in curricular and extra-curricular activities, behaviors of teachers, peers and school administration towards students and students' own efforts and devoting energy for acquiring educational outputs are very important for staying in school.

According to the developmental-transactional model (Jimerson et al., 2002), school dropout behavior is a result of a process. This process covers the first day in the first educational institution till the end of educational life. So, from the early developmental period of students, they start to interact with their surroundings and these experiences are transferred to the older ages. In this regard, early period home possessions, childcare, socioeconomic status, peer relations, academic achievement in secondary grades and family's school involvement are associated with dropping out of 19-year-old at-risk students.

Frustration-self-esteem and participation-identification models are proposed by Finn (1989). The first one explains how students build the road to dropout. In order to reinforce their broken self-esteem by failure or low achievement, students tend to find an area or a network where they seek to be accepted. Most of the time this network consists of students having a similar low achievement or problematic behaviors. The second one is about the road to school completion. In this model, students participating in the classroom activities start to reach the expected educational outputs even if these activities are needed a very low level of effort. The more students become successful the more they have a high level of involvement in school as an institution or school-related activities. Such a gradual development results in school completion.

Battin-Pearson and others (2000), proposed a five different model regarding school dropout. Among these models, academic mediation theory emphasizes that the academic achievement is the most powerful predictor of school dropout. General deviance theory explores the relationship between criminal behaviors, drug abuse and early pregnancy with the 
school dropout. Deviant affiliation theory emphasizes the link between school dropout and the student's network with antisocial peers. Antisocial peers have low engagement with the school and tend to dropout. Family socialization theory elaborates the association of family background and school dropout. In this context, family expectations from student education and the educational background of the family are very important. And lastly, the structural strains theory examines the link between school dropout and the sociodemographic factors such as gender, ethnicity or socioeconomic status.

The last approach for the explanation of the school dropout in K-12 education is the conceptual model of high school performance of Rumberger and Lim (2008), emphasizing that the school dropout as an output of educational performance (achievement, persistence, attainment). In this regard, educational performance is affected by individual and institutional factors. Individual factors consist of the student background, attitudes and behaviors, whereas institutional factors are composed of families, schools and communities.

Models or Conceptual Frameworks of Dropout in Postsecondary Education

As mentioned above, college dropout can be discussed in detail with the college retention theories. Frankly, college retention theories are commonly used for examining the student persistence and attrition in or departure from the college (Chen, 2008).

Tinto's (1987) student integration model is the best known and the most criticized among others. In this model, Tinto identifies a variety of external or pre-college factors that play a role in college student integration, including prior qualifications (grades, academic and social success, etc.), family attributes (social status, values, aspirations, etc.), individual attributes (gender, race, ability, etc.). He distinguishes between academic and social integration maintained by the experiences inside and outside of the classroom in an institutional environment. If social and academic interaction level increase, then does the student persistence in the college. According to Tinto (1987), there are three developmental stages for college students namely, separation, transition, and incorporation. In each period, students may decide to departure, but effective retention strategies assist students during the transition period. Although the model has been widely tested and used, it is criticized because of ignoring economic and external factors, and college types (residential and commuter colleges, two and four-year colleges) (Braxton \& Hirschy, 2005; Cabrera, Nora, \& Castaneda, 1993; Chen, 2008; Nora, Cabrera, Hagedorn, \& Pascarella, 1996; Tinto, 2006).

According to Astin's (1985) theory of student involvement, students' experiences in academic and extra-curricular activities are very important for their persistence. In this regard, college graduation is based on three correlational items as input, environment, and output. Inputs are directly or, considering the mediating role of the environment, indirectly related to outputs. Inputs include a variety of factors such as individual characteristics of the student, pre-tertiary experiences, and expectations from education, financial status or field of study. An environment is the place where students have their experiences during higher education. Various factors such as institutional opportunities, staff, education program, organizational climate, and academic and social activities are the important features of the environment. In this environment, students' time to continue to higher education and their experiences are considered as determining factors in student participation. Outputs are the results of experiences of students at the end of the higher education (Astin, 1993). Hence, inputs and various factors in the envi- ronment could be able to affect the student persistence and graduation from the college.

Pasceralla (1985) propose the general model for assessing change in student development. In this model Pascarella examines the role of five broad factors influencing the student during the higher education as (1) background characteristics, expectations and experiences of the student before the college, (2) institutional features of the higher education organization, (3) institutional environment, (4) the quality of the effort made by student, (5) interactions with faculty, peers and others, which could enable or hinder the student's learning and cognitive development.

Braxton and Hirschy (2005), propose two other theories for residential college retention and commuter college retention. The main difference between these two theories is the student's way of living in commuter and residential colleges. Students in commuter colleges hold their primary social memberships with family, friends and colleagues off campus and they may be older students working part time or full time (Braxton \& Hirschy, 2005). Hence, such factors inhibit developing relationships at college for commuter students (Alford, 1998). According to Braxton and Hirscy's theory for residential colleges, social integration has an important role directly on persistence. However, in their theory for commuter colleges, external environment and learning communities in academic communities play an important role directly on persistence.

All in all, these theories, models or approaches for explaining the dropout behavior in both K-12 and post-secondary education are complementary to each other in general, and it is obvious that none of them alone could explain the whole phenomena. However, most of them emphasize the role of individual or background characteristics of the students on the school dropout or college departure. And this study also examines these individual and sociodemographic factors as much as the data cover. Hence, the research questions are as follows:

1. What are the sociodemographic factors influencing the odds of school dropout?

2. What are the perceived factors influencing school dropout decision?

\section{Methods}

This study is designed as descriptive and correlational research, consisting the secondary analysis of FSS-2016 data. FSS-2016 identifies the structure of families, lifestyle of individuals in the family environment and values of individuals regarding family life in Turkey. It collects information on household characteristics, marriage, intrafamilial relations, relations with relatives, values and attitudes regarding children, elderly and other social issues and family problems (Family Structure Survey Micro Data Set, 2016).

\section{Population and the Sample}

The population of FSS-2016 is composed of all the people included in all the settlements in Turkey, except the institutional population living in dormitories, rest homes for elderly persons, special hospitals, military barracks and recreation quarters for officers etc. In this context, the unit of analysis is the individuals aged 15 and over. The sampling frame is based on Address Based Population Register System (ABPRS) and National Address Database (NAD). The stratified cluster sampling method was used to determine the number of households from 12 regions (NUTS 1 ) of Turkey. Finally, the data collected from 35,475 individuals in 17,239 households (Family Structure Survey Micro Data Set, 2016). 
Variables

There are two sets of variables for each one of the research questions. In this regard, for the first research question;

- The dependent variable

-Dropout status (DROPOUT): Whether the dropped out the school or not, including higher education.

- Independent variables

-Gender (GENDER): Gender of the participant. Two categories as female or male.

-Age (AGE): Completed age the participant. Age is used as both a continues and categoric variable regarding different analysis.

-Marital status (MARRIAGE): Current marital status Two categories as at least one marriage or never married.

-Work status (WORK): Working in a job at least one week from today. Two categories as worked or not worked.

-Residential area (AREA): Living location until the age of 15 . Four categories as province, county, village and abroad location.

-Living with father (LWF): How far living away from father. Three categories as living together, living separate and not having a father or died.

-Living with mother (LWM): How far living away from mother. Three categories as living together, living separate and not having a mother or died.

-Geographical location (REGION): 12 geographical location according to NUTS 1.

For the second research question, there is only one categorical variable which is represented by only one question: What is the most important reason for you to dropout? In this context, the categories regarding the perceived reasons to dropout are as follows:

1. Economic issues

2. Disallowing from going to school by the family

3. Inadequacy of teacher/school

4. Health issues

5. Academic failure

6. Getting married, engaged, pregnant or becoming mother/father

7. Other reasons

\section{Data Analysis}

There are different types of analysis for the research questions. For the first question binary logistic regression analysis was performed. And for the second question descriptive statistics were used.

For the first research question, there are two separate models for exploring the effect of sociodemographic variables on dropout behavior. One is for the whole participants and one is for the certain age groups. For both groups of participants, the logistic regression model, $\operatorname{Logit}\left(P_{i}\right)=\log \left[P_{i} /\left(1-P_{i}\right)\right]=p_{i}$, is the same.

For the whole group analysis there are two models. One is to control the effect of geographic location and the other one is for the full model including all independent variables. In this regard, the models are as follows:

- The first model for the analysis is $\operatorname{Logit}\left(P_{i}\right)=\beta_{0 i}+\beta_{1 i} R E G I O N+r_{i}$

- The second model for the analysis is $\operatorname{Logit}\left(P_{i}\right)=\beta_{0 i}+\beta_{1}$ GENDER $+\beta_{2 i}$ AGE $+\beta_{3 i}$ MARRIAGE $+\beta_{4 i}$ WORK $+\beta_{5 i}$ AREA $+\beta_{6 i} L W F+\beta_{7 i} L W M+$ $\beta_{8 i}$ REGION $+r_{i}$

For the age group analyses, there are again two models. One is to control the effect of geographic location and the other one is for the full model including all independent variables. Age is grouped into five categories as 15-17 years old, 18-24 years old, 25-44 years old, 45-64 years old and 65 and above ages. In this regard, the models are as follows:

- The first model for the analysis is $\operatorname{Logit}\left(\mathrm{P}_{\mathrm{i}}\right)=\beta_{0 i}+\beta_{1 i} \mathrm{REGION}+\mathrm{r}_{\mathrm{i}}$

-The second model for the analysis is $\operatorname{Logit}\left(\mathrm{P}_{\mathrm{i}}\right)=\beta_{0 i}+\beta_{1 i}$ GENDER $+\beta_{2 i}$ MARRIAGE $+\beta_{3 i}$ WORK $+\beta_{4 i}$ AREA $+\beta_{5 i} L W F+\beta_{6 i} L W M+\beta_{7 i}$ REGION $+r_{i}$

In the analysis of first research question, the purpose of using the REGION variable, despite the fact that it is not first level variable, is to obtain information about how much it predicts the likelihood of leaving school. The impact of interregional change is outside the scope of the study. By doing so, it was tried to understand to what extent the remaining variables predicted the possibility of leaving school, regardless of the differences between regions. Similarly, there are studies that use different level of variables in the same analysis together (Gumus \& Bellibas, 2016).

For the second research question, there are again two different analyses for the identification of perceived reasons to dropout. One for the whole participants and one for the above age groups. In the analyses, percentages and frequencies were calculated.

In the analysis of first research question, the purpose of using the REGION variable, despite the fact that it is not first level variable, is to obtain information about how much it predicts the likelihood of leaving school. The impact of interregional change is outside the scope of the study. By doing so, it was tried to understand to what extent the remaining variables predicted the possibility of leaving school, regardless of the differences between regions. Similarly, there are studies that use different level of variables in the same analysis together (Gumus \& Bellibas, 2016).

For the second research question, there are again two different analyses for the identification of perceived reasons to dropout. One for the whole participants and one for the above age groups. In the analyses, percentages and frequencies were calculated.

\section{Findings}

Before beginning the analyses, some certain assumptions and prerequisites for binary logistic regression analysis were checked (Şenel \& Alatlı, 2014). First, the data set has enough number of participants by the number of independent variables. Besides, missing values and outliers were controlled. There wasn't any multicollinearity problem among the variables. VIF values were far lower than 3.00 and the tolerance values were not close to 0.00 . In all models, both all age and specific age groups, Hosmer and Lemeshow goodness of fit 
index was $p>.05$. Moreover, for all models, Cook's Distance was less than 1, Leverage was between 0 and 1, DFBeta for the constant and the DFBeta for the First Predictor values were again less than 1 , and values for Studentized, Standardized Residuals and Deviance were again lying between the acceptable range (Field, 2009). In this regard, binary logistic regression analyses were performed.

However, before passing the specific findings regarding research questions, descriptive analyses were performed for identifying the general composition of the sample. Table 1 reveals the general characteristics of the non-dropouts and dropouts by independent variables (sociodemographic factors). In this context, only the gender has no relationship with being non-dropout or dropout for all sample. But gender was still controlled for the binary logistic regression analyses for specific age groups. Moreover, in this table region was shown as an independent variable. However, considering the focus of this study, the region is only a control/ dummy variable just to control the effect of regional characteristics. In other words, the region is only used to get more information on the change of its predictive power among other independent variables.

Table 1. Crosstabulations for Dropouts and non-Dropouts by Independent Variables

\begin{tabular}{|c|c|c|c|}
\hline Independent Variable & Non-Dropouts (\%) & Dropouts (\%) & $\mathrm{n}$ (Total) \\
\hline \multicolumn{4}{|l|}{ Gender } \\
\hline Female & 81.9 & 18.1 & 19701 \\
\hline Male & 81.4 & 18.6 & 15774 \\
\hline \multicolumn{4}{|l|}{ Marital status* } \\
\hline At least one marriage & 79.8 & 20.2 & 27903 \\
\hline Never married & 88.8 & 11.2 & 7572 \\
\hline \multicolumn{4}{|l|}{ Residential area* } \\
\hline Province & 83.2 & 16.8 & 11989 \\
\hline County & 80.7 & 19.3 & 9215 \\
\hline Village & 81.1 & 18.9 & 13757 \\
\hline Abroad & 81.5 & 18.5 & 514 \\
\hline \multicolumn{4}{|l|}{ Work status* } \\
\hline Didn't work & 82.5 & 17.5 & 21109 \\
\hline Worked & 80.5 & 19.5 & 14366 \\
\hline \multicolumn{4}{|c|}{ Living away from father (LWF)* } \\
\hline Same place & 87.5 & 12.5 & 6903 \\
\hline Different place & 79.4 & 20.6 & 11849 \\
\hline Not having a father/died & 80.9 & 19.1 & 16723 \\
\hline \multicolumn{4}{|c|}{ Living away from mother (LWM)* } \\
\hline Same place & 86.0 & 14.0 & 8467 \\
\hline Different place & 79.2 & 20.8 & 15092 \\
\hline Not having a mother/died & 81.8 & 18.2 & 11916 \\
\hline \multicolumn{4}{|l|}{ Age* } \\
\hline 15-17 years old & 93.8 & 6.2 & 2166 \\
\hline $18-24$ years old & 86.2 & 13.8 & 3961 \\
\hline 25-44 years old & 78.4 & 21.6 & 13699 \\
\hline 45-64 years old & 80.2 & 19.8 & 11008 \\
\hline 65 years old and above & 85.6 & 14.4 & 4641 \\
\hline \multicolumn{4}{|l|}{ Region* } \\
\hline TR1 & 82.1 & 17.9 & 4722 \\
\hline TR2 & 82.6 & 17.4 & 2231 \\
\hline TR3 & 82.2 & 17.8 & 5143 \\
\hline TR4 & 79.3 & 20.7 & 3251 \\
\hline TR5 & 84.2 & 15.8 & 4447 \\
\hline TR6 & 77.3 & 22.7 & 3673 \\
\hline TR7 & 82.0 & 18.0 & 2334 \\
\hline TR8 & 80.7 & 19.3 & 2344 \\
\hline TR9 & 81.1 & 18.9 & 1408 \\
\hline TRA & 85.1 & 14.9 & 1271 \\
\hline TRB & 83.7 & 16.3 & 1934 \\
\hline TRC & 81.9 & 18.1 & 2717 \\
\hline
\end{tabular}

*Chi square tests show significant differences between groups. ( $p<.001 ; n=35474)$ 
Table 2. Results of Stepwise Binary Logistic Regression Analysis Regarding the Relationship Between the Odds of Dropout and the Region for All Age Groups (Reference category: Being a non-dropout; $n=35475$ )

\begin{tabular}{|c|c|c|c|c|c|c|c|}
\hline \multirow{2}{*}{ Independent Variables } & \multirow{2}{*}{ B (SD) } & \multirow{2}{*}{ Wald } & \multirow{2}{*}{$d f$} & \multirow{2}{*}{$p$} & \multicolumn{3}{|c|}{ C.I. for $\operatorname{Exp}(B)$} \\
\hline & & & & & Lower & $\operatorname{Exp}(B)$ & Upper \\
\hline Constant & $-1.521(.038)$ & 1607.160 & 11 & .000 & & & \\
\hline \multicolumn{8}{|c|}{ Region (Reference category: TR1) } \\
\hline TR2 & $-.034(.067)$ & .260 & 1 & .610 & .846 & .966 & 1.103 \\
\hline TR3 & $-.010(.053)$ & .036 & 1 & .850 & .893 & .990 & 1.098 \\
\hline TR4 & $.179^{* \star *}(.058)$ & 9.727 & 1 & .002 & 1.069 & 1.197 & 1.339 \\
\hline TR5 & $-.150^{\star \star \star}(.056)$ & 7.222 & 1 & .007 & .771 & .860 & .960 \\
\hline TR6 & $.293^{* \star \star}(.055)$ & 28.593 & 1 & .000 & 1.204 & 1.340 & 1.491 \\
\hline TR7 & $.001(.066)$ & .000 & 1 & .988 & .880 & 1.001 & 1.139 \\
\hline TR8 & $.089(.065)$ & 1.891 & 1 & .169 & .963 & 1.093 & 1.241 \\
\hline TR9 & $.064(.078)$ & .665 & 1 & .415 & .915 & 1.066 & 1.241 \\
\hline TRA & $-.218^{*}(.087)$ & 6.232 & 1 & .013 & .678 & .804 & .954 \\
\hline TRB & $-.113(.072)$ & 2.428 & 1 & .119 & .776 & .894 & 1.029 \\
\hline TRC & $.012(.034)$ & .034 & 1 & .853 & .895 & 1.012 & 1.144 \\
\hline
\end{tabular}

Table 3. Results of Stepwise Binary Logistic Regression Analysis Regarding the Relationship Between the Odds of Dropout and Independent Variables for All Age Groups (Reference category: Being a non-dropout; $n=35475$ )

\begin{tabular}{|c|c|c|c|c|c|c|c|}
\hline \multirow{2}{*}{ Independent Variables } & \multirow{2}{*}{$B(S D)$} & \multirow{2}{*}{ Wald } & \multirow{2}{*}{$d f$} & \multirow{2}{*}{$p$} & \multicolumn{3}{|c|}{ C.I. for $\operatorname{Exp}(B)$} \\
\hline & & & & & Lower & $\operatorname{Exp}(B)$ & Upper \\
\hline Constant & $-1.95(.063)$ & 945.467 & 1 & .000 & & & \\
\hline Gender & & & 1 & & & & \\
\hline Male & $.094^{* * *}(.028)$ & 11.122 & 1 & .001 & 1.040 & 1.099 & 1.162 \\
\hline Marital status & & & 1 & & & & \\
\hline At least one marriage & $.912^{* * \star}(.061)$ & 220.354 & 1 & .000 & 2.207 & 2.490 & 2.809 \\
\hline Residential area & & 12.114 & 3 & .007 & & & \\
\hline County & $.126^{* * *}(.037)$ & 11.710 & 1 & .001 & 1.055 & 1.134 & 1.218 \\
\hline Village & $.076^{*}(.035)$ & 4.804 & 1 & .028 & 1.008 & 1.079 & 1.155 \\
\hline Abroad & $.029(.118)$ & .059 & 1 & .808 & .817 & 1.029 & 1.296 \\
\hline Work status & ------------- & ------- & ---- & ------- & ------- & ------- & ------ \\
\hline Worked & 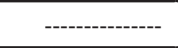 & 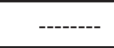 & $\begin{array}{ll}--- \\
-\end{array}$ & 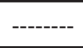 & (----- & - & -3 \\
\hline Living away from father (LWF) & & 30.066 & 2 & .000 & & & \\
\hline Different place & $.292^{\star \star \star}(.072)$ & 16.427 & 1 & .000 & 1.163 & 1.339 & 1.541 \\
\hline Not having a father/died & $.373^{* \star \star}(.069)$ & 29.112 & 1 & .000 & 1.268 & 1.452 & 1.663 \\
\hline $\begin{array}{l}\text { Living away from mother } \\
\text { (LWM) }\end{array}$ & & 8.019 & 2 & .018 & & & \\
\hline Different place & $-.182^{* *}(.065)$ & 7.916 & 1 & .005 & .734 & .833 & .946 \\
\hline Not having a mother/died & $-.163^{*}(.066)$ & 6.007 & 1 & .014 & .746 & .850 & .968 \\
\hline Age (Continuous) & $-.013^{* * *}(.001)$ & 83.406 & 1 & .001 & .985 & .987 & .990 \\
\hline Region (To control) & & 93.831 & 11 & .000 & & & \\
\hline
\end{tabular}

Findings for The First Research Question

Regarding the first research question, the first model examines the effect of region on the odds of being a dropout. This analysis is done just to see how much of the odds of being a non-dropout is explained by the region. In this context, according to the Table 2 , the region is only explaining the $0.4 \%$ of the odds of being a dropout, when the sample consists of all age groups.

Table 3 reveals that region and the all other variables together explain the $2.8 \%$ of the odds of dropout. According to this percentage, contribution of region in the explanation of the odds of dropout is very low (.04\%). When compared with the other variables, region is only contributing to the $1 / 7$ part of this explanation.

According to Table 3, gender, marital status, residential area, living away from mother and father have significant relationships with the odds of being a dropout like the region for all age groups. In this context, male dropout 1.10 times more than females. Individuals made at least one marriage dropout 2.49 times more than the individuals never married. Individuals lived in counties until the age of 15 dropout 1.13 times and individuals lived in villages until the age of 15 dropout 1.08 times more than individuals lived in provinces until the age of 15. Individuals living in a different place from father dropout 1.34 times, individuals not having a father or if their 
Table 4. Results of Stepwise Binary Logistic Regression Analysis Regarding the Relationship Between the Odds of Dropout and Independent Variables by Age Groups (Reference category: Being a non-dropout)

\begin{tabular}{|c|c|c|c|c|c|c|c|c|c|c|}
\hline \multirow{3}{*}{ Independent Variables } & \multicolumn{10}{|c|}{ Age Groups } \\
\hline & \multicolumn{2}{|c|}{$15-17(n=2166)^{1}$} & \multicolumn{2}{|c|}{$18-24(n=3961)^{2}$} & \multicolumn{2}{|c|}{$25-44(n=13699)^{3}$} & \multicolumn{2}{|c|}{$45-64(n=11008)^{4}$} & \multicolumn{2}{|c|}{$65+(n=4641)^{5}$} \\
\hline & B & $\operatorname{Exp}(B)$ & B & $\operatorname{Exp}(B)$ & B & $\operatorname{Exp}(B)$ & B & $\operatorname{Exp}(B)$ & B & $\operatorname{Exp}(B)$ \\
\hline Constant & -3.251 & .039 & -2.438 & .087 & -1.691 & .184 & -1.125 & .325 & -1.479 & .228 \\
\hline \multicolumn{11}{|l|}{ Gender } \\
\hline Male & --- & --- & --- & ---- & ---- & ---- & $.217^{\star \star \star}$ & 1.242 & $.233^{* \star *}$ & 1.263 \\
\hline \multicolumn{11}{|l|}{ Marital status } \\
\hline At least one marriage & $3.434^{* * *}$ & 30.995 & $.851^{* * *}$ & 2.342 & $.503^{* * *}$ & 1.654 & --- & --- & --- & ---- \\
\hline \multicolumn{11}{|l|}{ Residential area } \\
\hline County & -.128 & .88 & ---- & ---- & $.229^{* * *}$ & 1.257 & .034 & .614 & -.179 & .836 \\
\hline Village & $.579^{* *}$ & 1.784 & ---- & ---- & $.208^{* * *}$ & 1.232 & $-.139^{*}$ & .019 & $-.338^{* *}$ & .713 \\
\hline Abroad & 1.642 & 5.164 & ---- & ---- & .065 & 1.067 & -.069 & .706 & $-.661^{*}$ & .516 \\
\hline \multicolumn{11}{|l|}{ Work status } \\
\hline Worked & $1.551^{* * *}$ & 4.716 & $.447^{* * *}$ & 1.563 & $-.178^{* * *}$ & .837 & $-.125^{*}$ & .882 & --- & --- \\
\hline \multicolumn{11}{|c|}{ Living away from father (LWF) } \\
\hline Different place & --- & --- & $.475^{\star * \star}$ & 1.608 & ---- & ---- & ---- & --- & --- & --- \\
\hline Not having a father/died & --- & --- & $.824^{* * *}$ & 2.279 & ---- & ---- & --- & --- & --- & --- \\
\hline \multicolumn{11}{|c|}{ Living away from mother (LWM) } \\
\hline Different place & ---- & ---- & ---- & ---- & $-.216^{* *}$ & .806 & $-.258^{* *}$ & .772 & ---- & --- \\
\hline Not having a mother/died & ---- & --- & ---- & ---- & -.022 & .978 & $-.258^{* *}$ & .773 & ---- & ---- \\
\hline Region (To control) & ---- & --- & ---- & ---- & *** & *** & *** & *** & $* * *$ & *** \\
\hline
\end{tabular}

${ }^{*} p<.05 \cdot{ }^{* *} p<.01{ }^{* * * *} p<.001$

${ }_{1}^{1} R^{2}=6.030$ (Hosmer \& Lemeshow), 120 (Nagelkerke). Model $X^{2}(5)=99.049, p<.001 .{ }^{2} R^{2}=4.319$ (Hosmer \& Lemeshow), 0.073 (Nagelkerke). Model $X^{2}(4)=162.913, p<.001$. ${ }^{3} R^{2}=6.230$ (Hosmer \& Lemeshow), .016 (Nagelkerke). Model $X^{2}(18)=139.490, p<.001 .{ }^{4} R^{2}=10.436$ (Hosmer \& Lemeshow), 0.017 (Nagelkerke). Model $X^{2}(18)=118.046, p<.001$. ${ }^{5} R^{2}=7.104$ (Hosmer \& Lemeshow), .021 (Nagelkerke). Model $X^{2}(15)=54.630, p<.001$.

fathers are dead dropout 1.45 times more than individuals living with their fathers respectively. On the contrary, older individuals don't dropout $1.5 \%$ more than the youngers and individuals living in a different place from mother and individuals not having a mother or if their mothers are dead don't dropout 1.20 times and 1.18 times respectively more than the individuals living with their mothers. Work status is not a significant predictor of the odds of being a non-dropout when the sample composed of all age groups.

When the specific age groups are examined, all of the independent variables could show significant relationships with the odds of being a dropout. Table 4 shows a detailed examination of the independent variables.

For the individuals between 15-17 years old, marriage is increasing the odds of being a dropout 31.00 times (legally, a man or woman cannot marry unless he or she turns 17 in Turkey), while working is increasing the odds of being a dropout 4.72 times. Similarly, living in a village until 15 years old is increasing the odds of being a dropout 1.78 times. For the 18-24 age group, marriage is again increasing the odds of dropout, but this time, 2.34 times more. Similarly, working in a job at least for one week again increases the odds of being a dropout 1.56 times more. Besides, living in a different place from father and if he is dead increase the odds of being a dropout 1.61 times and 2.28 times more respectively. For the individuals between $25-44$ years old, marriage is again increasing the odds of being a dropout 1.65 times. Living in a county and living in a village until the age of 15 raise the odds of being a dropout 1.26 and 1.23 times more than living in a province until the age of 15 . But this time work status, decrease the odds of being a dropout 1.19 times. Similarly, living in a different place from mother drops the odds of being a dropout 1.24 times. For the 45-64 age group, a different variable, gender, comes to the forefront in explaining the dropout behavior of individuals. Being male boosts the odds of being a dropout 1.24 times more. As a contrary to its previous effect on dropout, this time living in a village decrease the odds of being a dropout 5.26 times. Similarly, work status reduces the odds of being a dropout 1.13 times. And again, living at a different place from mother and if the mother is dead decreasing the odds of being a dropout 1.30 times and 1.29 times more respectively. For the individuals, 65 and above years old, male dropout 1.26 times more than females, individual living in villages and abroad don't dropout 1.40 times and 1.94 times more respectively than the individuals living in provinces.

Moreover, when Table 5 is examined, region predicts the odds of being a dropout in a range between $0.4 \%$ and $1.5 \%$ in the above mentioned five age groups. And, there isn't any

Table 5. Prediction of the Odds of Being a Non-Dropout by Region According to the Results of Stepwise Binary Logistic Regression Analysis in Age Groups

\begin{tabular}{lrrrrr}
\hline Age groups & $n$ & Hosmer \& Lemeshow $X^{2}$ & Nagelkerke $R^{2}$ & Model $X^{2}$ & Model df \\
\hline $15-17$ years old & 2166 & .000 & .015 & 12.466 & 11 \\
\hline $18-24$ years old & 3961 & .000 & .012 & $26.925^{* *}$ & 11 \\
\hline 25-44 years old & 13699 & .000 & .004 & $38.884^{* * *}$ & 11 \\
\hline 45-64 years old & 11008 & .000 & .011 & $79.611^{* * *}$ & 11 \\
\hline 65 years old and above & 4641 & .000 & .014 & $35365^{* * *}$ & 11 \\
\hline
\end{tabular}

${ }^{*} p<.05 ;{ }^{* *} p<.01 ;{ }^{* * *} p<.001$ 
significant relationship between region and the odds of being a dropout for the 15-17 age group. When, Table 4 and 5 thought together, all independent variables in 15-17, 18-24, $25-44,45-64$ and $65+$ age groups, predict the $12.0 \%, 7.3 \%$, $1.6 \%, 1.7 \%$ and $2.1 \%$ of, whereas the region predicts $1.5 \%$, $1.2 \%, .04 \%, 1.1 \%$ and $1.4 \%$ the odds of dropout respectively. In this regard, the share of the region in this prediction is in $15-$ $17,18-24,25-44,45-64$ and $65+$ age groups are $\% 12.5, \% 16.4$, $\% 25.0, \% 64.7$ and \%66.7 respectively. Actually, this could be an important point showing that the effect of the region is becoming less important for today compared with the past in the dropout behavior of individuals.

Findings for the Second Research Question

The second research question is about to reveal the general reasons for dropping out perceived by the participants. In this context, Table 6 shows the percentages and frequencies of reasons to dropout as answered in the data set. For all age groups, economic issues, disallowing from going to school by the family and academic failure is the most important reasons to dropout respectively. When the age groups are compared in younger age groups, economic issues and disallowing from going to school by the family are getting less indicated; whereas the academic failure is getting more indicated. A similar change is seen in the inadequacy of teacher/school, which could mean recently, the inadequacy of teacher/school hasn't been an important reason to dropout when it compared with the distant past.

In order to give a detailed answer to the second research question and to see which reasons come to the forefront for male and female, Table 7 reveals the cross-tabulation results of gender by age groups. For all and specific age groups, perceived reasons show a significant relationship with the dropout behavior.

According to Table 7, economic issues and academic failure were indicated as the most important reasons to dropout for male, whereas disallowing from going to school by the family and getting married, engaged, pregnant or becoming mother were indicated as the most important reasons to dropout for female in all age groups. In detail, getting married, engaged, pregnant or becoming mother is forthcoming as an important reason to dropout for female in the 15-24 age group more than other ages. However, as the age of the participants increases, economic issues are indicated more by male than female. On the contrary, as the age increases, disallowing from going to school by the family is indicated more by female than male. However, this reason is actually notable for males in older ages despite any male don't indicate this is a valid reason to dropout in 15-17 age group.

Table 6. Numbers and Percentages of Perceived Factors Influencing School Dropout Decision by Age Groups

\begin{tabular}{|c|c|c|c|c|c|c|c|c|c|c|c|c|}
\hline \multirow[b]{3}{*}{ Reasons to Dropout } & \multicolumn{12}{|c|}{ Age Groups } \\
\hline & \multicolumn{2}{|c|}{ All Age Groups } & \multicolumn{2}{|c|}{ 15-17 Years Old } & \multicolumn{2}{|c|}{ 18-24 Years Old } & \multicolumn{2}{|c|}{ 25-44 Years Old } & \multicolumn{2}{|c|}{ 45-64 Years Old } & \multicolumn{2}{|c|}{65 Years Old and Above } \\
\hline & $n$ & $\%$ & $n$ & $\%$ & $n$ & $\%$ & $n$ & $\%$ & $n$ & $\%$ & $n$ & $\%$ \\
\hline Economic issues & 2835 & 43.6 & 31 & 23.0 & 207 & 37.8 & 1393 & 47.0 & 955 & 43.8 & 249 & 37.2 \\
\hline $\begin{array}{l}\text { Disallowing from going } \\
\text { to school by the family }\end{array}$ & 1647 & 25.4 & 13 & 9.6 & 91 & 16.6 & 643 & 21.7 & 635 & 29.1 & 265 & 39.6 \\
\hline $\begin{array}{l}\text { Inadequacy of teacher/ } \\
\text { school }\end{array}$ & 355 & 5.5 & 5 & 3.7 & 26 & 4.8 & 123 & 4.1 & 125 & 5.7 & 76 & 11.3 \\
\hline Health issues & 165 & 2.5 & 6 & 4.4 & 18 & 3.3 & 77 & 2.6 & 53 & 2.4 & 11 & 1.6 \\
\hline Academic failure & 726 & 11.2 & 69 & 51.1 & 122 & 22.3 & 309 & 10.4 & 190 & 8.7 & 36 & 5.4 \\
\hline $\begin{array}{l}\text { Getting married, } \\
\text { engaged, pregnant } \\
\text { or becoming mother/ } \\
\text { father }\end{array}$ & 395 & 6.1 & 3 & 2.2 & 41 & 7.5 & 259 & 8.7 & 70 & 3.2 & 22 & 3.3 \\
\hline Other reasons & 373 & 5.7 & 8 & 5.9 & 42 & 7.7 & 160 & 5.4 & 152 & 7.0 & 11 & 1.6 \\
\hline Total & 6496 & 100 & 135 & 100 & 547 & 100 & 2964 & 100 & 2180 & 100 & 670 & 100 \\
\hline
\end{tabular}

Table 7. Crosstabulations of Gender by Age Groups for Perceived Factors Influencing School Dropout Decision

\begin{tabular}{|c|c|c|c|c|c|c|c|c|c|c|c|c|}
\hline & \multicolumn{12}{|c|}{ Age Groups } \\
\hline & \multicolumn{2}{|c|}{ All Age Groups } & \multicolumn{2}{|c|}{$15-17$} & \multicolumn{2}{|c|}{$18-24$} & \multicolumn{2}{|c|}{$25-44$} & \multicolumn{2}{|c|}{$45-64$} & \multicolumn{2}{|c|}{$65+$} \\
\hline & Female & Male & Female & Male & Female & Male & Female & Male & Female & Male & Female & Male \\
\hline Total $(n)$ & 3561 & 2935 & 73 & 62 & 339 & 208 & 1703 & 1261 & 1104 & 1076 & 342 & 328 \\
\hline Reasons to Dropout & $\%$ & $\%$ & $\%$ & $\%$ & $\%$ & $\%$ & $\%$ & $\%$ & $\%$ & $\%$ & $\%$ & $\%$ \\
\hline Economic issues* & 30.7 & 59.4 & 32.9 & 11.3 & 35.4 & 41.8 & 34.8 & 63.5 & 27.1 & 61.0 & 16.7 & 58.5 \\
\hline $\begin{array}{l}\text { Disallowing from going to } \\
\text { school by the family* }\end{array}$ & 40.0 & 7.6 & 17.8 & .0 & 24.8 & 3.4 & 33.4 & 5.9 & 49.3 & 8.5 & 62.6 & 15.5 \\
\hline Inadequacy of teacher/school* & 4.7 & 6.4 & 2.7 & 4.8 & 4.1 & 5.8 & 3.9 & 4.5 & 5.2 & 6.3 & 7.9 & 14.9 \\
\hline Health issues $^{*}$ & 2.8 & 2.2 & 4.1 & 4.8 & 3.5 & 2.9 & 2.5 & 2.7 & 3.2 & 1.7 & 2.3 & 0.9 \\
\hline Academic failure* & 7.4 & 15.7 & 35.6 & 69.4 & 14.5 & 35.1 & 6.9 & 15.2 & 5.5 & 12.0 & 3.5 & 7.3 \\
\hline $\begin{array}{l}\text { Getting married, engaged, } \\
\text { pregnant or becoming mother/ } \\
\text { father }^{*}\end{array}$ & 9.9 & 1.4 & 2.7 & 1.6 & 11.8 & 0.5 & 13.6 & 2.1 & 5.4 & .9 & 5.8 & 0.6 \\
\hline Other reasons ${ }^{*}$ & 4.5 & 7.3 & 4.1 & 8.1 & 5.9 & 10.6 & 4.9 & 6.0 & 4.3 & 9.7 & 1.2 & 2.1 \\
\hline Total & 100 & 100 & 100 & 100 & 100 & 100 & 100 & 100 & 100 & 100 & 100 & 100 \\
\hline
\end{tabular}

*Chi square tests show significant differences between groups. $(p<.001)$ 


\section{Discussion}

According to the findings of the study, different variables show significant relationships with the odds of dropping out in all and specific age groups when the regional characteristics are controlled. In this regard, region explains a considerably low proportion of being dropout in lower age groups, but in older age groups like $45+$ region has gotten more percentage of prediction in the odds of dropping out. Specifically, in the 15-17 age group, there is not a significant relationship between region and the odds of dropout. In this regard, although the examination of the effect of different characteristics of the regions on the dropout behavior isn't the focus of this study, it should be noted that dropout behavior could be explained by different factors in different regions in Turkey (AÇEV, 2006; Boyacı \& Karacabey, 2018).

Another important factor in the explanation of the relationship between dropout and the sociodemographic factors is the gender, despite the crosstabulations in Table 1 shows no significant relationship between groups. Findings of gender reveal that in all and some specific age groups, male dropout more than female, especially in older ages as (45+). However, the role of gender on the dropout behavior is actually a controversial issue in the literature. In some studies (Andrei, Profiroiu, Profiroiu \& Jacob, 2011; MoNE, 2013; Sum et al., 2003; Uysal \& Şahin, 2009) male dropout more, but in other studies (AÇEV, 2006; Battin-Pearson et al., 2000; Rumberger, 2001) female dropout more. Furthermore, in some studies, gender doesn't make a significant difference in dropout behavior (Cataldi \& KewalRamani, 2009; Lan \& Lanthier, 2003).

Marital status, however, shows significant relationships in overall and younger age groups. In all these age groups, marriage, even it is only one time, increases the odds of dropout. Specifically, marriage is very disadvantageous to continue the education in 15-17 age group since it increases the odds of dropout 31 times more, but after 45 years and above age, marital status hasn't got any significant relationship with the odds of dropout. In this regard, marriage in younger ages, causing early transition into adult roles, increases the likelihood of dropout (Apel et. al., 2008; Epp \& Epp, 2001; Hupfeld, 2007; MoNE, 2013; Rumberger, 2004).

Moreover, findings show that residential area (individuals' location lived until the age of 15), plays an interesting role in the explanation of dropout behavior. For the younger age groups (15-24), in other words, for the recent past, living in counties or villages increases the odds of dropout. However, for the older age groups (45+), or for the distant past, living in villages decreases the odds of dropout compared with the living in provinces. Similar results could be seen in the literature regarding such a contradictory role of the residential area on dropout. For example, using the same dataset Roscigno and Crowle (2001) found that students in rural areas have lower achievement and higher dropout rates than the students in urban areas, whereas Fan and Chen (1999) proposes the opposite (Jordan, Kostandini, \& Mykerezi, 2012).

Different from all other independent variables, work status, doesn't have any significant relationship with the odds of dropout, and it isn't included in the stepwise regression model for all individuals. But, for the specific age groups, working in a job, boosts the odds of dropout in 24 and younger age groups, whereas it drops the odds of dropout in the ages between 25 and 64 . For 65 and older groups, the role of work status is insignificant in dropout behavior. For the 25 and above ages, such a finding is quite reasonable because these ranges are very appropriate to work for normal individuals. However, in younger ages, especially in high school years, working increases the likelihood of dropping out (Boyacı \& Karacabey, 2018; Rumberger, 2004; Warren \& Cataldi, 2006). Besides, working in younger ages could also be taken into consideration as a factor in easing the transition into adult roles, which also produce negative results for the students (Hupfeld, 2007).

Leaving away from father and mother are taken as two different variables in the study. Although they are similar to each other, they play a different role in explaining the dropout behavior. Living in different places from father and not having a father or if he is dead, the odds of dropout is increasing in the 18-24 age group; however, in the 25-64 age group, living in different places from mother and not having a mother or if she is dead, the odds of dropout is decreasing. This could be the result of the composition of the sample. In the sample of this study, the ratio of living away from father in the group of individuals living with their mothers in the same place is much more than the ratio of living away from mother in the group of individuals living with their fathers in the same place, especially in older ages. In other words, individuals living in the same place with mother, living in separate families much more than the individuals living in the same place with father and this become much more apparent in older age groups. Hence, living away from mother could be effective in decreasing the odds of dropout. Below Table 8, shows these ratios for all of the sample.

In this regard, different studies found similar results showing that living in families other than biological parents, single-parent families or stepparent families raise the odds of dropout and sustain low achievement both in Turkish and international literature (Alkan, 2014; Kaufman et al., 1992; Rumberger \& Lim, 2008; Teachman et al., 1996).

Considering the findings about the perceived reasons to dropout, especially for the younger age groups, economic issues and academic failure become more apparent in explaining the dropout behavior for all the individuals in the sample. Actually, low academic achievement and economic issues are represented as the major factors leading school dropout in a broad range of literature (AÇEV, 2006; Alexander et al., 2001; Allensworth \& Easton, 2007; Battin-Pearson

Table 8. Crosstabulation Results Between Living Away from Mother (LWM) and Living Away from Father (LWF)

\begin{tabular}{|c|c|c|c|c|c|c|}
\hline & & & \multicolumn{4}{|c|}{ Living Away from Father (LWF) } \\
\hline & & & Same place & Different place & Not having a father/dead & Total \\
\hline \multirow{6}{*}{$\begin{array}{l}\text { Living Away from } \\
\text { Mother (LWM) }\end{array}$} & \multirow{2}{*}{ Same place } & $n$ & 6517 & 478 & 1472 & 8467 \\
\hline & & $\%$ & 77 & 5.6 & 17.4 & 100 \\
\hline & \multirow{2}{*}{ Different place } & $n$ & 70 & 10016 & 5006 & 15092 \\
\hline & & $\%$ & .5 & 66.4 & 33.2 & 100 \\
\hline & \multirow{2}{*}{ Not having a mother/dead } & $n$ & 316 & 1355 & 10245 & 11916 \\
\hline & & $\%$ & 2.7 & 11.4 & 86.0 & 100 \\
\hline \multirow{2}{*}{ Total } & & $n$ & 6903 & 11849 & 16723 & 35475 \\
\hline & & $\%$ & 19.5 & 33.4 & 47.1 & 100 \\
\hline
\end{tabular}


et al., 2000; Boyacı \& Karacabey, 2018; Christensen \& Thurlow, 2004; Dynarski \& Gleason, 2002; Mahuteau \& Mavromas, 2014; MoNE, 2013; Randolph, Fraser \& Ornthner 2006; Rumberger \& Lim, 2008; Tunç, 2011). Similarly, for both female and male in younger age groups, inadequacy of teacher/school is becoming a less indicated reason.

Moreover, there are different reasons to dropout for female and male. Specifically, disallowing from going to school by the family is a distinctive reason for females. Also, the AÇEV (2006) report emphasized this situation, but in this study, in younger age groups disallowing from going to school by the family is less emphasized by the female participants. Similarly, most of the time, economic issues an important reason to dropout for male. As a conclusion, for younger groups, it could be said that the reasons for dropout is becoming more convergent regarding the gender. In other words, for the recent past, economic issues and academic failure are existing as major factors to dropout, replacing others.

\section{Conclusion}

When all the independent variables examined one by one, region is a significant predictor of the odds of being a dropout for the individuals $25+$ years old. Similarly, considering prediction percentages of region in Table 5 and the prediction percentages with other variables in Table 4, beginning from the 25-44 age group, region is becoming the major independent variable explaining the odds of being a dropout. However, its percentage of prediction is going down in the younger age groups. Hence, once again the effect of regional characteristics or differences is becoming less effective in explaining the dropout behavior among individuals in recent past.

Moreover, gender is only a significant predictor of dropout for the individuals 45 and above years old. This could mean in recent past the education system has become more inclusive compared with at least 40 or 50 years ago. Actually, schooling rates are quite similar between girls and boys in K-16 education. Marital status, however, is not a significant predictor of dropout for the individuals 45 and above years old, but for younger generations. Actually, this is quite reasonable thinking the latest theoretical education year is about 30 years.

Residential area until the age of 15, is another important variable showing the background characteristics of individuals could affect the dropout behavior in coming years. In other words, for the individuals 45 and above years old living in villages or abroad are advantageous for school completion, but for younger generations provinces is advantageous to continue the education. A possible explanation of this change could be massification in the number of schools and students in provinces. In other words, in provinces individuals have more chances to access to school and educational material. Actually, crosstabulations between perceived reasons to dropout and residential area show that even in the recent past inadequacy of teacher/school has been decreased and it was more apparent in all age groups for individuals living in villages and counties.

Work status, or working in a job, decreases the risk of dropping out in the 25 years and above; whereas it boosts the risk of dropping out among the individuals 24 years and under. Such findings are quite reasonable again considering the working age is considered in between 15 and 65 years of age by OECD (data.oecd.org); however, in younger ages than 25 , it is quite risky for school completion.

Living with father is quite important to continue the education in 18-24 age group. However, living away from mother is promoting not to dropout for the individuals between 25-64 years of age. Frankly, this is a very interesting finding. However, the crosstabulations between living away from father and mother reveals that, individuals living with their fathers, also have a greater ratio of living together with their mothers, but individuals living with their mothers, have a greater ratio of most of living separated from their fathers and this becomes clear in older ages. In other words, in the scope of the sample of this study, living together with father means living as a whole family more than living with mother. Living as whole family is more advantageous to continue the education than living in a separated family.

Regarding perceived reasons to dropout, economic issues, disallowing from going to school by the family and academic failure is the major obstacle for school completion for all individuals in the sample. However, in all age groups, economic issues and academic failure are the most important reasons to dropout for male, whereas disallowing from going to school by the family and getting married, engaged, pregnant or becoming mother are the most important reasons to dropout for female. When compared with the older age groups, economic and issues and academic reasons come to forefront among other reasons in younger age groups. In other words, reasons are converging in recent years. Besides, inadequacy of teacher/school is again less emphasized in recent past.

\section{Suggestions}

According to the findings of the study, different factors could be affective on dropout behavior in different age groups. Since this study covers dropout both in K-12 and post-secondary education, and thinking the at most theoretical education age is about 30 , it could be said that any suggestions based on the results of this study should focus on the possible solutions of the dropout problem in younger age groups. In this regard, being married, working in a job, living in a village or county and living away from father or in a separated family are the urgent sociodemographic problems leading dropout. Besides, economic issues and low achievement is the major reasons to dropout according to the participants who dropped out.

In this context, for the elimination of the negative effect of sociodemographic factors, there is needed a collective action planned by different ministries of the government at the national level. Because, school dropout is actually a broad problem not only for the individual or the family, but for the whole society. Hence, firstly, an action plan should be prepared for the collective campaign to reduce the dropout rates in the whole country, supported by the government at high level.

Moreover, the findings of this study suggest that individuals living in separated families, working in a job and living in rural areas until the age of 15 are automatically at high-risk group for dropout. In this regard, at the institutional level, school managers or principals should be aware of these students and take care of them closely with an effective use of guidance and consultancy services in schools. Besides, these efforts should not only focus on enhancing the social conditions of the students but also school authorities should focus on eliminating the low academic achievement, figuring out the academic failure is very substantial to dropout. Similarly, in the local level, municipalities or other local authorities should support the families of these students, in collaboration with schools, considering the economic issues is one of the most important reason to dropout, especially in younger age groups. But these efforts should be extended until reaching to the smallest residential area.

School dropout is an important challenge in the Turkish educational system. More research is needed to investigate the common factors causing dropout in general, but even more important task may be to identify the local factors in different geographical areas. A close research collaboration with local public-school authorities and universities can enhance our research-based knowledge base and can contribute to research-based decision making to combat dropout in the future. 


\section{References}

Alexander, K. L., Entwisle, D. R., \& Horsey, C. S. (1997). From first grade forward: Early foundations of high school dropout. Sociology of Education, 70(2), 87-107.

Alkan, E. Ö. (2014). Parçalanmış Aile Modelindeki Öğrencilerin Eğitimdeki Başarı Durumları (Trabzon Örneği). Unpublished Doctoral Dissertation. Inonu University, Malatya, Turkey.

Allensworth, E. M., \& Easton, J. Q. (2007). What Matters for Staying On-Track and Graduating in Chicago Public High Schools: A Close Look at Course Grades, Failures, and Attendance in the Freshman Year. Research Report. Consortium on Chicago School Research and perceptions of school and self before dropping out of schools. Journal of Education for Students Placed at Risk, 8(3), 309-332.

Andrei, T., Profiroiu, A., Profiroiu, M., \& lacob, A. I. (2011). School dropout in Romania at the level of disadvantaged groups. Procedia-Social and Behavioral Sciences, 28, 337-341.

Apel, R., Bushway, S. D., Paternoster, R., Brame, R., \& Sweeten, G. (2008). Using state child labor laws to identify the causal effect of youth employment on deviant behavior and academic achievement. Journal of Quantitative Criminology, 24(4), 337-362.

Astin, A. W. (1985). Achieving educational excellence. San Francisco: Jossey-Bass.

Battin-Pearson, S., Newcomb, M. D., Abbott, R. D., Hill, K. G., Catalano, R. F., \& Hawkins, J. D. (2000). Predictors of early high school dropout: A test of five theories. Journal of educational psychology, 92(3), 568-582.

Belfield, C. R., \& Levin, H. M. (Eds.). (2007). The price we pay: Economic and social consequences of inadequate education. Brookings Institution Press.

Boyacı, A., Karacabey, M. F., \& Öz, Y. Açık Meslek Liselerinin Okul Terkleriyle Başa Çıkma Kapasitesini Zorlayan Örgütsel Sorunlar. Turkish Online Journal of Qualitative Inquiry, 9(1), 1-25.

Braxton, J. M., \& Hirschy, A. S. (2005). Theoretical developments in the study of college student departure. In E. Siedman (Ed.) College student retention: Formula for student success, (pp. 61-87). Westport: Praeger Publishers.

Bülbül, T. (2012). Yükseköğretimde okul terki: Nedenler ve çözümler. Eğitim ve Bilim, 37(166), 219-235.

Cabrera, A. F., Nora, A., \& Castaneda, M. B. (1993). College persistence: Structural equations modeling test of an integrated model of student retention. Journal of Higher Education, 64(2), 123-139.

Cataldi, E. F., \& KewalRamani, A. (2009). High School Dropout and Completion Rates in the United States: 2007 Compendium Report. NCES 2009-064. National Center for Education Statistics, U.S. Department of Education. https://nces.ed.gov/pubs2009/2009064. pdf (Accessed on 05/11/2018)

Chen, R. (2008). Financial aid and student dropout in higher education: A heterogeneous research approach. In J. C. Smart (Ed.), Higher Education: Handbook of Theory and Research (pp. 209-239). Netherlands: Springer.
Christenson, S. L., \& Thurlow, M. L. (2004). School dropouts: Prevention considerations, interventions, and challenges. Current Directions in Psychological Science, 13(1), 36-39.

Epp, J. R., \& Epp, W. (2001). Easy exit: School policies and student attrition. Journal of Education for Students Placed at Risk, 6(3), 231-247.

Family Structure Survey Micro Data Set. (2016). http://www. tuik.gov.tr/MicroVeri/Aile_2016/english/meta-data/ purpose/index.html (Accessed on 05/11/2018)

Fan, X., \& Chen, M. J. (1998). Academic Achievement of Rural School Students: A Multi-Year Comparison with Their Peers in Suburban and Urban Schools.

Field, A. (2009). Discovering statistics using SPSS. Sage Publications.

Finn, J. D. (1989). Withdrawing from school. Review of Educational Research, 59, 117-142.

Gleason, P., \& Dynarski, M. (2002). Do we know whom to serve? Issues in using risk factors to identify dropouts. Journal of Education for Students Placed at Risk, $7(1), 25-41$.

Gökşen, F., Cemalcılar, Z. \& Gülselel, C.F. (2006). Türkiye'de ilköğretim okullarında okulu terk ve izlenmesi ile önlenmesine yönelik politikalar. İstanbul: AÇEV, ERG, KADER, AB.

Gumus, E., \& Bellibas, M. S. (2016). The effects of professional development activities on principals' perceived instructional leadership practices: multi-country data analysis using TALIS 2013. Educational Studies, 42(3), 287-301.

Hupfeld, K. (2007). Resiliency skills and dropout prevention: A review of the literature. Denver: ScholarCentric.

Israel, G. D., \& Beaulieu, L. J. (2004). Laying the foundation for employment: The role of social capital in educational achievement. The Review of Regional Studies, 34(3), 260-287.

Jimerson, S. R., Ferguson, P., Whipple, A. D., Anderson, G. E., \& Dalton, M. J. (2002). Exploring the association between grade retention and dropout: A longitudinal study examining socio-emotional, behavioral, and achievement characteristics of retained students. The California School Psychologist, 7(1), 51-62.

Jimerson, S., Egeland, B., Sroufe, L. A., \& Carlson, B. (2000). A prospective longitudinal study of high school dropouts examining multiple predictors across development. Journal of School Psychology, 38(6), 525-549.

Jordan, L., Kostandini, G., \& Mykerezi, E. (2012). Rural and urban high school dropout rates: Are they different? Journal of Research in Rural Education (Online), 27(12), 1.

Jordan, W. J., Lara, J., \& McPartland, J. M. (1996). Exploring the causes of early dropout among race-ethnic and gender groups. Youth \& Society, 28(1), 62-94.

Karacabey, M. F., \& Boyacl, A. (2018). Okulu Terkeden Ortaöğretim Öğrencilerinin Okulu Terk Etme Nedenleri ve Sosyo-Ekonomik Profilleri: Şanlıurfa Örneği. Kuram ve Uygulamada Eğitim Yönetimi Dergisi, 24(2), 247-293. 
Kronick, R. F. (1994). The imperative of dealing with dropouts: theory, practice and reform. Education, 114(4), 530 538.

Lamborn, S., Newmann, F., \& Wehlage, G. (1992). The significance and sources of student engagement. In F.N. Newmann (Ed.), Student engagement and achievement in American secondary schools, pp. 11-39. New York: Teachers College Press.

Lan, W., \& Lanthier, R. (2003). Changes in students' academic performance.

Mahuteau, S., \& Mavromaras, K. (2014). An analysis of the impact of socio-economic disadvantage and school quality on the probability of school dropout. Education Economics, 22(4), 389-411.

MoNE. (2013). Ortaöğretimde sınıf tekrarı, okul terk sebepler ve örgün eğitim dışında kalan çocuklar politika önerileri raporu. http://www.meb.gov.tr/earged/unicef/ Sınıf\%20Tekrarı,\%200kul\%20Terki\%20Politika\%20 Raporu.pdf (Accessed on 05/11/2018)

Nora, A., Cabrera, A., Hagedorn, L. S., \& Pascarella, E. (1996). Differential impacts of academic and social experiences on college-related behavioral outcomes across different ethnic and gender groups at four-year institutions. Research in higher education, 37(4), 427-451.

Özdemir, S., Erkan, S., Karip, E., Sezgin, F., \& Şirin, H. (2010). ilköğretim okulu öğrencilerinin okulu terk etme nedenleri ve çözüm önerileri. Ankara: TÜBiTAK Proje No: 107K453. http://gef-egitimbilimleri-egitimyonetimi.gazi.edu.tr/ posts/download?id=31921 (Accessed on 05/11/2018)

Özer, A., Gençtanirim, D., \& Ergene, T. (2011). Türk lise öğrencilerinde okul terkinin yordanması: aracı ve etkileşim değişkenleri ile bir model testi. Education in science: the bulletin of the Association for Science Education, 36(161), 302-317.

Pascarella, E. T. (1985). College environmental influences on learning and development: A critical review and synthesis. In J. C. Smart (Ed.), Higher education: Handbook of theory and research (1st ed.). New York, NY: Agathon.

Randolph, K. A., Fraser, M. W., \& Orthner, D. K. (2006). A strategy for assessing the impact of time-varying family risk factors on high school dropout. Journal of Family Issues, 27(7), 933-950.

Roscigno, V. J., \& Crowle, M. L. (2001). Rurality, institutional disadvantage, and achievement/attainment. Rural Sociology, 66(2), 268-292.

Rumberger, R. W. (2001). Why students drop out of school and what can be done. Paper Presented for Conference: Dropouts in Americe: How severe is the problem? What do we know about intervention and prevention? Harvard Graduate School of Education, Cambridge, MA.

Rumberger, R. W., \& Lim, S. A. (2008). Why students drop out of school: A review of 25 years of research. California Dropout Research Project, 15, 1-3.

Şenel, S., \& Alatlı, B. (2014). Lojistik regresyon analizinin kullanıldığı makaleler üzerine bir inceleme. Eğitimde ve Psikolojide Ölçme ve Değerlendirme Dergisi, 5(1), 35-52.

Stearns, E., \& Glennie, E. J. (2006). When and why dropouts leave high school. Youth \& Society, 38(1), 29-57.
Sum, A., Harrington, P., Bartishevich, C., Fogg, N., Khatiwada, I., Motroni, J., Palma, S., Pond, N., Tobar, P., \& Trub'skyy, M. (2003, February). The hidden crisis in the high school dropout problems of young adults in the U.S.: Recent trends in overall school dropout rates and gender differences in dropout behavior. Boston, MA Center for Labor Market Studies, Northeastern University, prepared for The Business Roundtable.

Tinto, V. (1987). Leaving college: Rethinking the causes and cures of student attrition. Chicago: University of Chicago Press.

Tinto, V. (2006). Research and practice of student retention: What next? Journal of College Student Retention: Research, Theory \& Practice, 8(1), 1-19.

Tunç, A. İ. (2009). Kız çocuklarının okula gitmeme nedenleri (Van ili örneği). Yüzüncü Yıl Üniversitesi Eğitim Fakültesi Dergisi, 6(1), 237-269.

Uysal, A. (2008). Okulu bırakma sorunu üzerine tartışmalar: çevresel faktörler. Milli Eğitim, 178, 139-150.

Uysal, A., \& Şahin, Y. (2007). Ortaöğretimde Okulu Bırakma Olgusunu Tetikleyen Yapısal/ Çevresel Faktörler, 16. Eğitim Bilimleri Kongresi, Osmangazi Üniversitesi, Tokat, Türkiye.

Warren, J. R., \& Cataldi, E. F. (2006, March). A historical perspective on high school students' paid employment and its association with high school dropout. In Sociological Forum (Vol. 21, No. 1, pp. 113-143). Springer US.

http://tegm.meb.gov.tr (Accessed on 05/11/2018)

http://www.ikg.gov.tr/ozellikle-kiz-cocuklarinin-okullasma-oranlarinin-artirilmasi-operasyonu/ (Accessed on 05/11/2018)

https://data.oecd.org/emp/employment-rate-by-age-group. htm (Accessed on 05/11/2018)

https://data.worldbank.org/indicator/SE.COM.DURS?end=20 $17 \&$ start=2016\&view=chart $($ Accessed on 05/11/2018) 